\title{
Tobacco excise taxes and rates of smokeless tobacco use in the US: an exploratory ecological analysis
}

\author{
Robert L Ohsfeldt, Raymond G Boyle
}

\begin{abstract}
Objective - To determine the association between state tobacco excise tax rates and the rate of smokeless tobacco use in the US.

Design - A single cross-section of state level data for 1985 are used in a multivariate regression model controlling for ability to pay, educational attainment, consumer preferences, and state tobacco regulation.
\end{abstract}

Results-State-level prevalence of smokeless tobacco use among males 16 and older ranged from $23.1 \%$ in West Virginia to less than $1 \%$ in several states including Connecticut, Hawaii, and Massachusetts. The multivariate results indicate that higher excise taxes applied to smokeless tobacco products are associated with lower rates of smokeless tobacco use among males aged 16 and older, holding other factors constant. In addition, higher cigarette tax rates are associated with higher rates of smokeless tobacco use, holding smokeless tobacco excise tax rates and other factors constant.

Conclusion-Tax-induced relative price changes could be one factor among a multitude of factors affecting the growth in smokeless tobacco use among young males in the 1980 s. Increases in smokeless tobacco excise tax rates may be an important part of a comprehensive effort to reduce the use of smokeless tobacco.

Department of Health Care Organization and Policy, School of Public Health, University of Alabama at Alabama at Birmingham, Alabama, USA RL Ohsfeldt

Tobacco Research Laboratory, School of Medicine, University of Minnesota, Minneapolis, Minnesota, USA RG Boyle

Correspondence to Dr Robert L Ohsfeldt, School of Public Health, University of Alabama at Birmingham,

Birmingham, Alabam 35294-2010, USA young males. ${ }^{1}$ This growth has been tied to the marketing of moist snuff tow young males. From 1970 to 85, the percentag of males aged 16-19 years using moist snuff increased by ninefold from $0.3 \%$ to $2.9 \%$. For all smokeless tobacco products, prevalence of use among this age group increased from $1.4 \%$ to $5.9 \%$ (figure 1 ). ${ }^{2}$ Among older males (aged 20 and older), the prevalence of use increased by $16 \%$, from $4.9 \%$ to $5.7 \%$. By 1991 , about $5.6 \%$ of males aged 18 and older used smokeless tobacco. ${ }^{3}$ Consumption behaviour favouring moist snuff products presents serious cancer and oral pathology risks. ${ }^{4}$

In contrast, the prevalence of cigarette smoking in the US has been decreasing. From 1970 to 85 , cigarette smoking declined by $27 \%$ among male smokers aged 16-19 years and among males aged 20 and older smoking declined by $25 \%$, from $44.3 \%$ to $33.2 \%$ (figure 1). By 1991, about $28.1 \%$ of males aged 18 and older smoked cigarettes. ${ }^{5}$

A number of factors have contributed to the decline in smoking prevalence. Among these factors are various federal and state policies to control access to tobacco products. Excise taxes represent an indirect control measure in that the higher prices caused by taxes make tobacco products less affordable. Past studies have indicated that higher prices, created in part by increases in federal and state cigarette taxes, reduce cigarette consumption. ${ }^{6-10}$ The most dramatic evidence of this effect is from Canada, where excise tax increases in the 1980s contributed to steep increases in retail cigarette prices - until recent tax roll-backs, cigarette taxes represented about $75 \%$ of the retail price of cigarettes in Canada. Per capita cigarette consumption declined in Canada over this period more rapidly than in the US. ${ }^{11}$

Considerable attention has been given to increasing excise taxes on products such as alcohol and tobacco as a means of health promotion. ${ }^{12}$ In 1985, compared to cigarette excise taxes, excise taxes applied to smokeless tobacco products were low - there was no federal excise tax on smokeless tobacco and only 21 states levied an excise tax on smokeless tobacco products. From 1985 through 1993, 22 states raised or implemented excise taxes on smokeless tobacco products. The federal excise tax rate now is 2.8 cents per $1.2 \mathrm{oz}$ can of snuff and 2.4 cents per $3 \mathrm{oz}$ pouch of chewing tobacco. Although it is plausible to speculate that higher smokeless tobacco excise taxes will reduce the use of smokeless tobacco, no published study has attempted to verify the effect empirically. The objective of this study was to estimate the association between state 

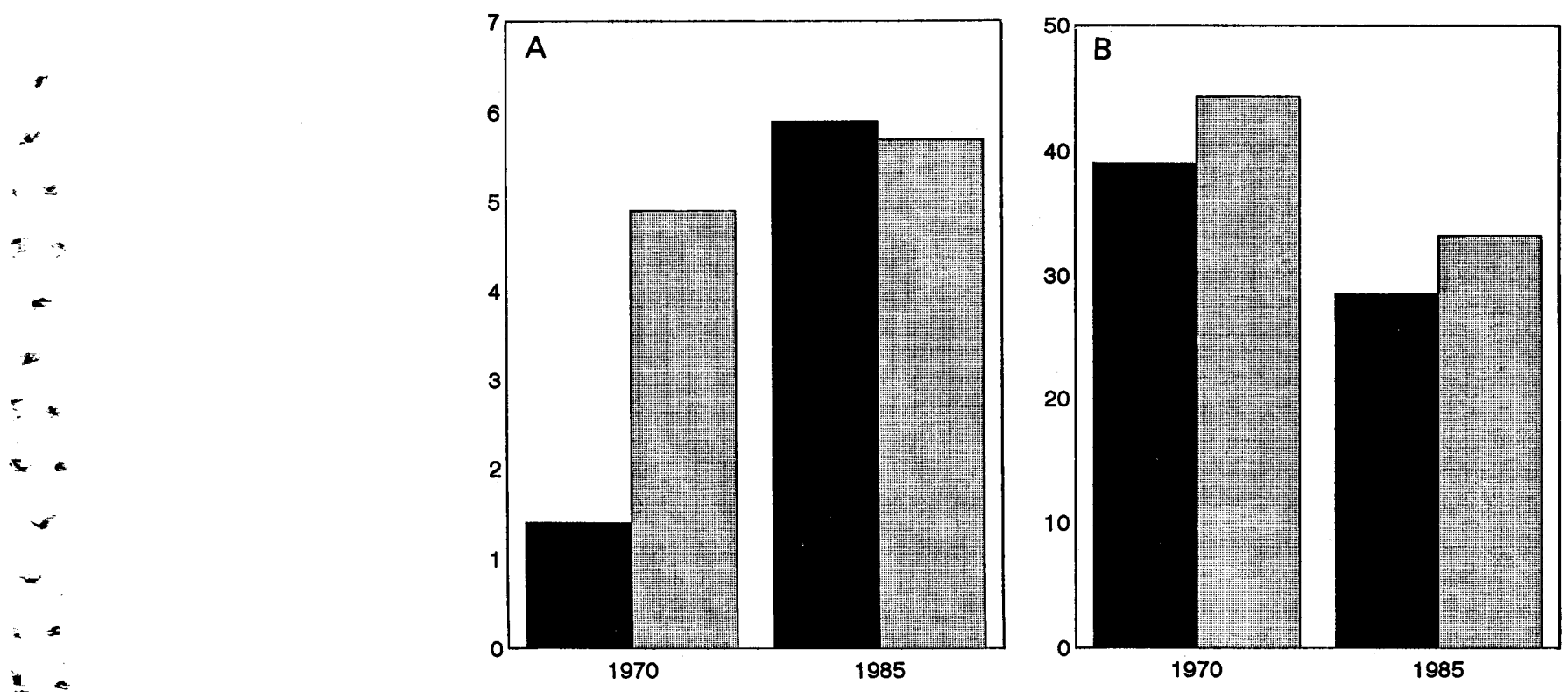

Figure 1 Percentage of US males using tobacco by type of tobacco and age group; $(A)$ cigarettes, $(B)$ smokeless tobacco. Black: age 16-19 years; grey: 20 or over.

smokeless tobacco excise tax rates and the rate of use of smokeless tobacco using a single cross-section of state-level data for 1985 .

\section{Methods}

To isolate the association between tobacco excise tax rates and use rates, a multivariate regression model was used to control for other factors in states hypothesised to affect the prevalence of smokeless tobacco use among males aged 16 and older. All analyses were performed using the statistical software package SAS. The alpha level for data analysis was set at 0.10 ; thus statistical differences were declared significant at $\mathrm{p}<0.10$.

\section{DEPENDENT VARIABLES}

Three measures of smokeless tobacco use were used as dependent variables in the empirical model: $a$ ) the prevalence of snuff use; $b$ ) the prevalence of chewing tobacco use; and $c$ ) the prevalence of use of either form of smokeless tobacco. These data were obtained from Marcus et al, who derived state-level use prevalence rate estimates from the September 1985 Current Population Survey (CPS). ${ }^{2}$ Although these data now are somewhat old, more recent data are not available. (The public use version of the data file for the National Health Interview Survey does not indicate state of residence.) The prevalence measures are expressed in terms of their natural logarithms to reduce cross-sectional heteroskedasticity. The CPS only provides data for any level of use, not the intensity of use among those using smokeless tobacco products. Thus, only the first-part of a standard two-part demand model can be estimated using the CPS data. Smokeless tobacco use at any level may be less responsive to economic control variables (eg, taxes) than the intensity of use among users. However, the factors predicting complete absence of use may be of greater policy relevance than factors incrementally reducing the intensity of use.

\section{INDEPENDENT VARIABLES}

The selection of independent variables included in the empirical model is based in part on the economic literature examining the effects of cigarette taxes on cigarette demand. ${ }^{6,7}$ Independent variables are grouped in the following categories:

\section{State excise taxes on tobacco}

All states had a special excise tax on cigarettes in place in 1985 , but only 20 states had special excise taxes applied to snuff and 21 states had excise taxes for chewing tobacco (figure 2) ${ }^{13} \mathrm{It}$ is likely that state excise taxes on smokeless tobacco products have some impact on the demand for these products, as higher taxes are passed on to consumers as higher prices. Four measures of state tobacco excise taxes are used in the model. Three of these correspond to the three measures of smokeless tobacco use: $a$ ) the excise tax rate for snuff; $b$ ) the excise tax rate for chewing tobacco; and $c$ ) the weighted average of the two tax rates as a "smokeless tobacco" tax rate measure. All of these tax rates are expressed as a percentage of the wholesale price of the product. The state excise tax per pack of cigarettes, adjusted for differences across states in general price levels, also is included to capture any cross-tax effects.

To account for the impact of possible border crossing for purchases of tobacco, border-state adjusted excise tax rate measures are constructed for each state. For each of the four excise taxes, the border-state adjusted tax rate for each state is the weighted average of the state's tax rate and the minimum of the state's tax rate and the tax rate in a neighbouring state, across all neighbouring states. The weights are the percentages of a state's population living within 20 miles (about $32 \mathrm{~km}$ ) of 

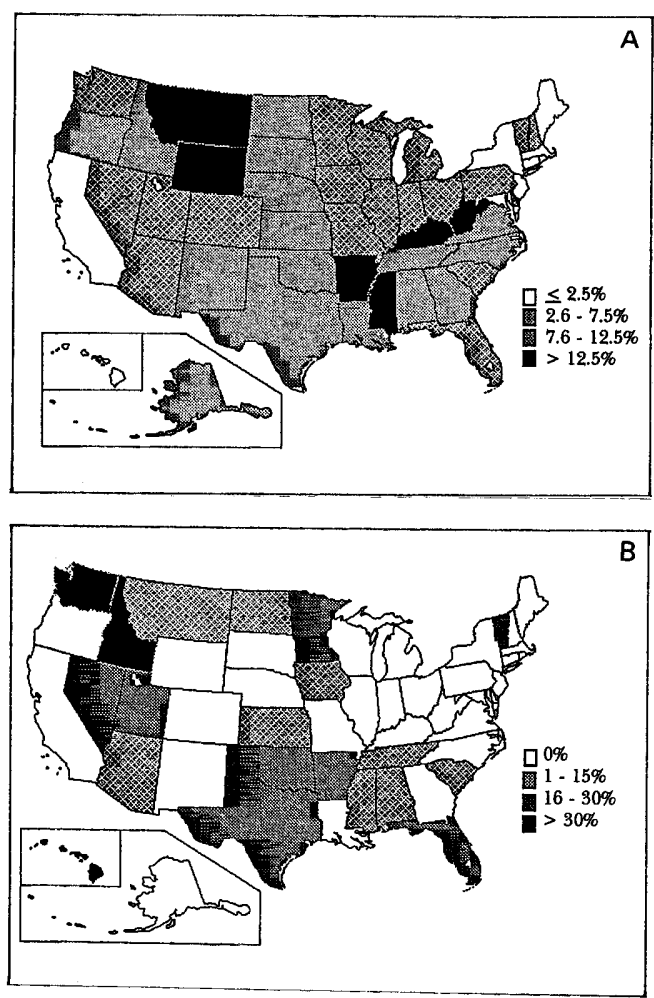

Figure 2 (A) Prevalence rates of smokeless tobacco use in the US, males aged 16 years and older, 1985; $(B)$ chewing tobacco excise tax rates in the US as a percentage of wholesale price, 1985.

the border of each bordering state, with a residual weight for the percentage of the population not within 20 miles of any other state. The "minimum" operator is used because border-crossing behaviour, if present, is expected to be dominated by crossing from a high-tax state into a nearby low-tax state to purchase the tobacco product at a lower price, not vice versa. Thus, the border-adjusted average excise tax rates for some states are lower than the state's actual tax rate, but the adjusted tax rate is never higher than the actual rate. The model does not account for local (city or county) tobacco tax rates.

Ability to pay

Per capita personal income, adjusted for differences across states in general price levels, is used to capture the ability to pay for tobacco and other products. Higher income would be associated with greater demand for smokeless tobacco products, other things the same, if smokeless tobacco products are normal goods (in the economic sense of the term "normal good"). Higher income would be associated with lower demand if smokeless tobacco products were inferior goods (again in the economic sense of "inferior good").

\section{Education}

Educational attainment is often used in economic models of health behaviour as a technological factor in an individual's production of health. ${ }^{14}$ The notion is that education improves the efficiency of an individual's use of health information and choices affecting health. This implies that greater educational attainment reduces the likelihood that an individual engages in unhealthy behaviours, such as smokeless tobacco use. Alternatively, low educational attainment may be related to a high rate of time preference across individuals. An individual with a high rate of time preference may be more likely than others to engage in behaviour that generates current satisfaction at a future cost. In either case, higher educational attainment is expected to be associated with a lower rate of smokeless tobacco use. The percentage of the population aged 25 or older who are high school graduates is included in the empirical model as a measure of average educational attainment.

\section{Consumer preferences}

Several characteristics of a state's population are included in the model to capture systematic differences in consumer preferences for smokeless tobacco products. Residence in a southern state often is cited as a risk factor for smokeless tobacco use. ${ }^{2} \mathrm{~A}$ binary variable equal to one for southern states thus is included in the model. Since white males are thought to be at greater risk than black males ${ }^{2}$, the percentage of the male population 16 and older who are black is included in the model. Fundamentalist Protestant denominations generally have a negative view of tobacco use. Variables indicating the percentage of the population who are adherents to fundamentalist Protestant denominations and the percentage of the population with no active religious affiliation thus are included in the model. ${ }^{15,16}$ The divorce rate, which is often used as a measure of stress in smoking studies, also is included. Finally, a preference for smokeless tobacco use may be associated with outdoor activity. The percentage of the state population age 16 or older who hunted or fished in 1985 is included to account for this possibility. ${ }^{17}$

State tobacco use regulation

At least some studies indicate that state laws restricting smoking in public places reduce the demand for cigarettes. ${ }^{9,10}$ Such laws could encourage the use of smokeless tobacco in place of smoked tobacco products, if smokeless tobacco use were not covered by the laws, if smokeless tobacco use were more difficult to detect, or if laws as they apply to smokeless tobacco were less strictly enforced. Pertschuck and Shopland summarise, by state, the presence of statutes restricting smoking in 17 general categories of public places. ${ }^{18}$ (No such compilation is available concerning state laws restricting the public use of smokeless tobacco.) The small sample size available for the empirical analysis and multicollinearity prevented the use of numerous binary variables for various types of smoking restrictions in the regression model. Cluster analysis was used to determine if state tobacco laws could be coded into a binary variable indicating the presence of more restrictive laws. The 17 categories of 
places covered by state laws were coded as variables indicating the presence or absence of regulation in each of the 17 areas. A single linkage or nearest-neighbour method of agglomerative clustering was used. Cases and clusters with the shortest euclidian distance were combined until a single cluster was formed. The results indicated that a binary classification was appropriate. A binary variable equal to one for states in the restrictive cluster is included in the empirical model. The model does not account for local laws restricting smoking, which generally are more restrictive than state laws.

A final independent variable is the percentage of the male population aged 16 or older who were aged $16-17$ in $1985 .^{19}$ Such individuals may have reduced access to smokeless tobacco products relative to older males due to laws prohibiting sales to persons under the age of 18. Although enforcement is notoriously lax, these laws could reduce the use of smokeless tobacco among this age cohort relative to older males. On the other hand, age may be related to personal preferences for smokeless tobacco. If the youngest males have a greater preference for smokeless tobacco than older males, the impact of any reduced access related to age could be obscured.

\section{ESTIMATION ISSUES}

To determine the effect of smokeless tobacco excise taxes on smokeless tobacco use, the possibility that the size of the excise tax is affected by the level of use (ie, the tax rate is endogenous for the use rate) should be considered. A Hausman test for the null hypothesis that each of the excise tax rate variables is not correlated with the error term in the use rate regressions rejected the null hypothesis $(\mathrm{p}<0.01)$ in each case. ${ }^{20}$ Thus, an instrumental variable (IV) approach was used to purge the correlation between the excise tax variables and the error term in the smokeless tobacco use equations. ${ }^{20}$ Each of the tax rate variables was regressed on a series of statelevel variables including all of the variables listed above and the following variables: percent metropolitan population, unemployment rate, indices of political liberalism and interparty political competition, per capita state government tax revenues, and the size of age groups among males age 16 and older, as shown in Appendix I. Note that in the reduced-form models of state tobacco excise tax rate determination, greater liberalism is associated with higher tax rates for both cigarettes and smokeless tobacco products. Higher educational attainment among a state's population is associated with higher smokeless tobacco taxes but not higher cigarette taxes. Higher per capita income in a state is associated with higher cigarette taxes but income has no statistical association with smokeless tobacco excise taxes.

Some past studies suggest that state smoking laws may be endogenous for rates of cigarette smoking (ie, states with a low prevalence of cigarette smoking may more readily adopt laws restricting smoking). ${ }^{7,21}$ However, the smoking law variable is treated as exogenous for smokeless tobacco use since a Hausman test could not reject the null hypothesis of zero correlation between the smoking law variable and the error term in the smokeless tobacco use equations.

A well-known problem is that the CPS data contain a number of proxy responses for tobacco use, particularly for teenagers. ${ }^{2}$ Although all surveys eliciting self-reported tobacco use measure use with error, there is the potential for more substantial underreporting of use by proxy respondents. Despite the error in the CPS measure of smokeless tobacco use prevalence, estimates of the effects of variance in taxes on variance in prevalence of smokeless tobacco use may be unbiased if response error is uncorrelated with tax rates or other variables in the demand model. It is possible that proxy response bias accounts in part for the apparent endogeneity of smokeless tobacco tax rates for reported smokeless tobacco use. If so, the IV approach employed in the analysis should serve to purge the effects of systematic proxy response bias from model estimates of the excise tax coefficients.

Finally, the relatively small sample size requires the use of a parsimonious model specification. Alternative model specifications were estimated to assess the sensitivity of the estimated excise tax coefficients to the choice of regressors used in the model.

\section{Results}

Results for two specifications of the model for each of the three measures of smokeless tobacco use are reported in table 1 . The second specification of each use rate model (Model B) excludes the restrictive public smoking law variable and other variables in the full model (Model A) that were not statistically significant in any of the three use-rate equations. Standard error estimates are reported in parentheses below the estimated coefficients. A description of and sample means for the model variables can be found in Appendix II.

\section{MOIST SNUFF AND CHEWING TOBACCO TAXES}

Regarding the use of snuff, in the full model (Model A), the estimated coefficient of the snuff tax variable is negative and statistically significant $(p<0.1)$. The point estimate becomes larger in magnitude and precision improves $(p<0.01)$ when the abbreviated model specification is used (Model B). Evaluated at sample means, the tax elasticity of snuff prevalence (ie, the percent change in the use rate given a $1 \%$ change in the tax rate), is about -0.4 to -0.6 (table 2 ). Recall, however, that both the snuff use rate and snuff excise tax rate are expressed as percentages. Thus, a $10 \%$ increase from the mean excise tax rate (from $8.0 \%$ to $8.8 \%$ of the wholesale price) is associated with a reduction in the snuff use prevalence rate of about $4 \%$ to $6 \%$ (ie, from $1.9 \%$ users to $1.82 \%$ or $1.78 \%$ users), other things constant. 
Table 1 Estimates of state-level prevalence of use of snuff and chewing tobacco among males aged 16 years or more, 1985

\begin{tabular}{|c|c|c|c|c|c|c|}
\hline & \multicolumn{2}{|c|}{$\log ($ snuff $)$} & \multicolumn{2}{|c|}{$\log$ (chewing tobacco) } & \multicolumn{2}{|c|}{$\log$ (any smokeless) } \\
\hline & Model $A$ & Model B & Model $A$ & Model B & Model $A$ & Model B \\
\hline Intercept & $\begin{array}{c}5.93^{\mathrm{b}} \\
(2.61)\end{array}$ & $\begin{array}{c}5.27^{\mathrm{b}} \\
(2.14)\end{array}$ & $\begin{array}{r}3.59^{\mathrm{c}} \\
(1.89)\end{array}$ & $\begin{array}{r}3.75^{\mathrm{b}} \\
(1.53)\end{array}$ & $\begin{array}{r}4.68^{\mathrm{b}} \\
(1.88)\end{array}$ & $\begin{array}{r}4.64^{\mathrm{a}} \\
(1.52)\end{array}$ \\
\hline Snuff tax & $\begin{array}{r}-5.62^{\mathrm{c}} \\
(3.26)\end{array}$ & $\begin{array}{r}-8.40^{\mathrm{a}} \\
(2.15)\end{array}$ & - & - & - & - \\
\hline Chew tax & - & - & $\begin{array}{r}-8.39^{\mathrm{a}} \\
(2.24)\end{array}$ & $\begin{array}{r}-7.39^{\mathrm{a}} \\
(1.61)\end{array}$ & - & - \\
\hline Smokeless tax & - & - & - & - & $\begin{array}{r}-7.29^{\mathrm{a}} \\
(2.28)\end{array}$ & $\begin{array}{r}-7.35^{\mathrm{a}} \\
(1.58)\end{array}$ \\
\hline Cigarette tax & $\begin{array}{l}2.45^{\mathrm{c}} \\
(1.55)\end{array}$ & $\begin{array}{r}3.87^{\mathrm{a}} \\
(1.15)\end{array}$ & $\begin{array}{c}3.09^{\mathrm{b}} \\
(1.18)\end{array}$ & $\begin{array}{r}2.37^{\mathrm{a}} \\
(0.91)\end{array}$ & $\begin{array}{r}2.79^{\mathrm{b}} \\
(1.16)\end{array}$ & $\begin{array}{r}2.58^{\mathrm{a}} \\
(0.87)\end{array}$ \\
\hline Per capita income & $\begin{array}{r}-0.067^{\mathrm{e}} \\
(0.036)\end{array}$ & $\begin{array}{r}-0.11^{2} \\
(0.02)\end{array}$ & $\begin{array}{r}-0.075^{a} \\
(0.025)\end{array}$ & $\begin{array}{r}-0.072^{\mathrm{a}} \\
(0.017)\end{array}$ & $\begin{array}{r}-0.073^{\mathrm{a}} \\
(0.025)\end{array}$ & $\begin{array}{r}-0.081^{a} \\
(0.016)\end{array}$ \\
\hline High school graduate (\%) & $\begin{array}{c}-0.039 \\
(0.036)\end{array}$ & - & $\begin{array}{c}0.010 \\
(0.024)\end{array}$ & - & $\begin{array}{r}-0.003 \\
(0.024)\end{array}$ & - \\
\hline Fundamentalist $(\%)$ & $\begin{array}{c}0.027 \\
(0.021)\end{array}$ & $\begin{array}{c}0.036^{\mathrm{b}} \\
(0.016)\end{array}$ & $\begin{array}{r}0.053^{a} \\
(0.015)\end{array}$ & $\begin{array}{r}0.042^{\mathrm{a}} \\
(0.012)\end{array}$ & $\begin{array}{r}0.042^{c} \\
(0.022)\end{array}$ & $\begin{array}{c}0.037^{\mathrm{a}} \\
(0.012)\end{array}$ \\
\hline To religion $(\%)$ & $\begin{array}{c}0.022 \\
(0.015)\end{array}$ & $\begin{array}{c}0.029^{b} \\
(0.011)\end{array}$ & $\begin{array}{r}0.039^{2} \\
(0.011)\end{array}$ & $\begin{array}{r}0.032^{2} \\
(0.008)\end{array}$ & $\begin{array}{r}0.032^{\mathrm{a}} \\
(0.011)\end{array}$ & $\begin{array}{r}0.030^{\mathrm{a}} \\
(0.008)\end{array}$ \\
\hline Southern states & $\begin{array}{l}0.16 \\
(0.48)\end{array}$ & $\begin{array}{c}0.32 \\
(0.27)\end{array}$ & $\begin{array}{c}0.68^{\mathrm{b}} \\
(0.34)\end{array}$ & $\begin{array}{c}0.61^{\mathrm{a}} \\
(0.19)\end{array}$ & $\begin{array}{c}0.49 \\
(0.35)\end{array}$ & $\begin{array}{l}0.52^{\mathrm{a}} \\
(0.19)\end{array}$ \\
\hline Smoking laws & $\begin{array}{r}-0.18 \\
(0.25)\end{array}$ & - & $\begin{array}{r}-0.19 \\
(0.18)\end{array}$ & - & $\begin{array}{c}-0.21 \\
(0.18)\end{array}$ & - \\
\hline Hunt/fish (\%) & $\begin{array}{r}0.062^{a} \\
(0.014)\end{array}$ & $\begin{array}{c}0.057^{\mathrm{a}} \\
(0.011)\end{array}$ & $\begin{array}{r}0.053^{\mathrm{a}} \\
(0.009)\end{array}$ & $\begin{array}{r}0.054^{\mathrm{a}} \\
(0.008)\end{array}$ & $\begin{array}{r}0.057^{\mathrm{a}} \\
(0.010)\end{array}$ & $\begin{array}{r}0.056^{\mathrm{a}} \\
(0.008)\end{array}$ \\
\hline Divorce rate & $\begin{array}{c}0.044 \\
(0.069)\end{array}$ & - & $\begin{array}{c}-0.043 \\
(0.048)\end{array}$ & - & $\begin{array}{r}-0.015 \\
(0.049)\end{array}$ & - \\
\hline Males $16-17(\%)$ & $\begin{array}{c}-9.92^{\mathrm{b}} \\
(0.45)\end{array}$ & $\begin{array}{r}-1.18^{\mathrm{a}} \\
(0.38)\end{array}$ & $\begin{array}{c}-1.09^{\mathrm{a}} \\
(0.33)\end{array}$ & $\begin{array}{r}-0.92^{\mathrm{a}} \\
(0.29)\end{array}$ & $\begin{array}{c}-0.99^{\mathrm{a}} \\
(0.33)\end{array}$ & $\begin{array}{r}-0.94^{\mathrm{a}} \\
(0.28)\end{array}$ \\
\hline Males Black (\%) & $\begin{array}{c}-0.029 \\
(0.023)\end{array}$ & - & $\begin{array}{r}-0.005 \\
(0.017)\end{array}$ & - & $\begin{array}{c}-0.009 \\
(0.017)\end{array}$ & - \\
\hline
\end{tabular}

Note: Estimated standard errors for coefficients are indicated in parentheses. Model B excludes variables not statistically significant in Model A for any of the smokeless tobacco use measures.

${ }^{\mathrm{a}} \mathrm{p}<0.01$; $^{\mathrm{b}} \mathrm{p}<0.05$; $^{\mathrm{c}} \mathrm{p}<0.10$.

Table 2 Estimated tax elasticities of smokeless tobacco product use prevalence, 1985 sample means

\begin{tabular}{lccc}
\hline \multicolumn{1}{c}{ Tax } & Snuff & Chew & $\begin{array}{c}\text { Any } \\
\text { smokeless }\end{array}$ \\
\hline Snuff & -0.41 & - & - \\
Chew & $-0.61]$ & -0.63 & - \\
Smokeless & - & {$[-0.56]$} & -0.55 \\
Cigarette & 0.39 & - & {$[-0.55]$} \\
& {$[0.62]$} & {$[0.49]$} & 0.44 \\
& & & $0.41]$ \\
\hline
\end{tabular}

Note: Elasticity estimates reported in parentheses are calculated from Model B in table 1.

Similarly, in the chewing tobacco use model, the estimated coefficients of the state chewing tobacco excise tax rate (table 1 , columns 3 and 4) are negative and significant $(\mathrm{p}<0.01)$ in both model specifications. The point estimate of the tax elasticity (at means) is about -0.6 (see table 2). Finally, in the combined smokeless tobacco use model, the estimated coefficient of the constructed smokeless tobacco excise tax rate is negative and significant $(\mathrm{p}<$ 0.01 ) in both model specifications (columns 5 and 6 ). The estimated smokeless tobacco tax elasticity is about -0.55 , implying that a $10 \%$ increase in the smokeless tobacco tax rate would reduce smokeless tobacco use rates by about $5.5 \%$ (see table 2).

CROSS-TAX EFFECTS

In terms of cross-tax effects, the estimated coefficient of the cigarette excise tax variable is positive and statistically significant $(p<0.1)$ in all of the models presented in table 1 . The point estimate of the cross-tax elasticity is about 0.4 to 0.6 for snuff use rates (see table 2).
This implies that a $10 \%$ increase in the cigarette excise tax rate would be expected to result in a $4 \%$ to $6 \%$ increase in snuff use rates. For the chewing tobacco use models, the point estimates indicate a cross-elasticity for chewing tobacco use of about 0.4 to 0.5 (see table 2). The estimated cross-tax effects are similar in magnitude in the combined smokeless tobacco use model.

\section{OTHER VARIABLES}

Regarding other model variables, higher per capita income is associated with lower rates of smokeless tobacco use, suggesting that smokeless tobacco is an inferior good. Residents of southern states are more likely than residents of non-southern states to use chewing tobacco. States with a relatively large percentage of fundamentalist Protestant population have higher rates of chewing tobacco use, as do states with a relatively large percentage of population with no active religious affiliation. Higher rates of hunting and fishing are associated with greater use of smokeless tobacco. Of course, these associations could represent ecological fallacy (eg, a high percentage fundamentalist population may be associated with a greater rate of use across states, but among individual residents of each state a fundamentalist may be less likely than others to use). The smoking law variable, when included in the model, is not associated with the use of smokeless tobacco products. The same lack of association is evident for the divorce rate, high school graduation rates, and the percentage of the state's male population that is black. Finally, states with a relatively large share of males 16 and older in the 16-17 
year age group have lower rates of chewing tobacco use. This could reflect the impact of access restrictions, or it could simply be an artifact of the reporting bias associated with proxy respondents for adolescents (recall however that the use prevalence measures in the model exclude males under 16).

$\bar{x}$

\section{- Discussion}

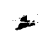

$=$ *

$5<$

$\sim$

$\dot{-1}$

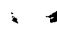

5

$-$

$<$

$\therefore<$

$=2$

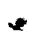

$\sim$

$-$

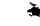

- 4

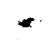

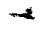

$\div$

$1=$

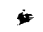

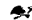

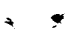

$=$ -

*.

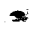

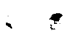

$=2$

$\checkmark$

$<$
The results indicate that higher excise taxes on smokeless tobacco products are associated with lower rates of smokeless tobacco use, holding other factors constant. The magnitudes of the implied tax effects on use rates generally are consistent with the effects of cigarette prices on cigarette use found in past studies. Keeler et $\mathrm{al}^{9}$, using monthly cigarette sales for California during 1980-90, conclude that the price elasticity of cigarette demand was -0.4 to -0.6 , depending on the specification of the model. Using state-level sales data pooled over time, Baltagi and Levin ${ }^{6}$ and Chaloupka and Saffer ${ }^{7}$ find cigarette demand price elasticities of -0.2 and -0.3 , respectively. Similarly, Wasserman et $a l,{ }^{10}$ using self-reported cigarette use data from the National Health Interview Surveys, conclude that the cigarette price elasticity was about -0.3 among adults in the late 1980s. Becker $e t a l^{22}$ conclude the price elasticity of cigarette demand is about -0.75 , if the longrun effect of price changes on cigarette use is taken into account.

Although the smokeless tobacco excise tax elasticities reported here correspond to the high end of past cigarette demand price elasticity estimates, it should be noted that our model uses state excise taxes rather than prices, since state-level retail prices for smokeless tobacco products are not available. If differences in excise taxes translate directly to proportionate differences in retail prices, the price elasticity should be somewhat higher than the tax elasticity, because taxes paid per unit are but one component of the full retail price (ie, a particular tax increase representing a $10 \%$ increase in the tax rate represents much less than a $10 \%$ increase in retail price). Thus, our results suggest that smokeless tobacco demand is at least as responsive to its own price as cigarette demand. State laws restricting public smoking do not appear to affect rates of smokeless tobacco use.

The model estimates also imply that raising cigarette excise tax rates will increase the rate of use of smokeless tobacco, holding smokeless tobacco tax rates constant. The estimated cross-tax effects are not trivial in magnitude, particularly in light of large increases in federal and state cigarette excise tax rates over the past decade, and the magnitude of tax increases that have been proposed for the future. Although the magnitudes of the cross-tax elasticities in part are due to the small "base" of smokeless tobacco use (ie, a small increase from nearly zero is a large percentage increase), it is possible that the cross-tax effects would be even more substantial if the model accounted for the quantity of smokeless tobacco products used, not just the presence or absence of any level of use. Indeed, about a quarter of adults who used smokeless tobacco in 1991 also smoked cigarettes. ${ }^{5}$ On the other hand, the estimated cross-tax effects may be inflated if there are factors affecting smokeless tobacco use correlated with state cigarette excise tax rates not accounted for in the model. However, it is unlikely that such unmeasured confounding factors would completely eliminate a cross-tax effect.

The apparent magnitude of the cross-tax effect may reflect the dominant presence of young males among smokeless tobacco users particularly snuff. ${ }^{2}$ In other words, if the demand for cigarettes among young males is more responsive to changes in cigarette prices, the cross-price effect of cigarette price increases on smokeless product demand also may be larger in magnitude for young males than for other persons. Lewit $e t a l^{23}$ conclude that the price elasticity of cigarette demand among teenagers is -1.2 to -1.4 , implying that teenagers are much more responsive to price changes than adults. However, Chaloupka ${ }^{24}$ and Wasserman et $a l^{10}$ conclude that cigarette demand among teenagers is less responsive to price than among adults. Thus, own- and cross-tax effects of tobacco excise taxes may be quite different for other population groups.

Over the past decade, both federal and state governments have used cigarette excise tax increases to maintain or increase tax revenues, as well as to discourage cigarette use. In many states the price of smokeless tobacco products fell relative to the price of cigarettes during the 1980 s, making smokeless tobacco a relatively economical alternative to cigarettes - particularly for those least able to pay higher cigarette prices (eg, young males). Indeed, moist snuff advertisements during the 1980s targeted at youth stressed that snuff use was very "economical". " Our results suggest that taxinduced relative price changes could be one factor among the multitude of factors affecting the growth in smokeless tobacco use among young males in the 1980s. By way of analogy, DiNardo and Lemieux ${ }^{25}$ observe that increases in state minimum drinking age laws during the 1980 s caused substitution of marijuana for alcohol use among high school seniors. In other words, individuals may respond to efforts to control the use of a particular drug by substituting an alternative drug not subject to increased control effort. The results presented here imply that an unintended consequence of further increases in cigarette tax rates could be an increased rate of smokeless tobacco use, if smokeless tobacco tax rates are not also increased.

Additional research using more complete data is needed to more precisely assess the impact of tobacco excise tax rate changes and other control efforts on the use of smokeless tobacco. Increases in smokeless tobacco excise tax rates may be an important part of a comprehensive effort to reduce the use of smokeless tobacco, and thereby reduce the incidence of disease caused by smokeless tobacco use. Of course, the optimal tax rates for each of the various types of tobacco 
products depend in part upon how the products are used, the costs created by use, the responses of users to changes in prices, and the effectiveness of alternative control efforts. ${ }^{26,27}$ However, any significant cross-price effects should be taken into account when assessing the advisability of an excise tax increase for any particular tobacco product.

The participation of Raymond Boyle in this study was supported by NIDA grant no DA $05844-05$.

Appendix I Reduced-form estimates of state tobacco excise tax rates

\begin{tabular}{|c|c|c|c|c|}
\hline \multirow[b]{2}{*}{ Independent variable } & \multicolumn{4}{|c|}{ Dependent variable } \\
\hline & Snuff tax & Chew tax & $\begin{array}{l}\text { Smokeless } \\
\text { tax }\end{array}$ & $\begin{array}{l}\text { Cigarette } \\
\text { tax }\end{array}$ \\
\hline Intercept & 0.032 & 0.253 & 0.176 & 0.79 \\
\hline Per capita income & $(1.45)$ & (1.37) & $(1.40)$ & $(0.34)$ \\
\hline Per capita income & $\begin{array}{c}-0.001 \\
(0.002)\end{array}$ & $\begin{array}{c}-0.001 \\
(0.002)\end{array}$ & $\begin{aligned}-0.0005 \\
(0.002)\end{aligned}$ & $0.008^{\mathrm{c}}$ \\
\hline High school graduates (\%) & $0.013^{\mathrm{b}}$ & $0.013^{\mathrm{b}}$ & $0.013^{\mathrm{b}}$ & $\begin{array}{c}(0.004) \\
0.002\end{array}$ \\
\hline & $(0.006)$ & $(0.006)$ & $(0.006)$ & $(0.014)$ \\
\hline Unemployment rate & 0.002 & 0.001 & 0.002 & 0.013 \\
\hline Metro population (\%) & $\begin{array}{c}(0.013) \\
0.002\end{array}$ & $(0.012)$ & $(0.012)$ & $(0.030)$ \\
\hline Metro population (\%) & $\begin{array}{c}0.002 \\
(0.002)\end{array}$ & $\begin{array}{c}0.002 \\
(0.001)\end{array}$ & $\begin{array}{c}0.002 \\
(0.001)\end{array}$ & $\begin{array}{c}0.0006 \\
(0.0004)\end{array}$ \\
\hline Fundamentalist $(\%)$ & 0.003 & $0.003^{c}$ & 0.003 & $-0.001^{b}$ \\
\hline & $\left(\begin{array}{c}0.002) \\
0.003\end{array}\right.$ & $(0.002)$ & $(0.002)$ & $(0.0005)$ \\
\hline No religion $(\%)$ & $\begin{array}{c}0.003 \\
(0.002)\end{array}$ & $\begin{array}{c}0.003 \\
(0.002)\end{array}$ & $\begin{array}{c}0.003 \\
(0.002)\end{array}$ & $\begin{array}{r}-0.0005 \\
(0.0004)\end{array}$ \\
\hline Southern state & 0.103 & 0.122 & 0.115 & 0.015 \\
\hline & $(0.082)$ & $(0.077)$ & $(0.079)$ & $(0.019)$ \\
\hline Smoking laws & 0.033 & 0.024 & 0.027 & 0.002 \\
\hline Hunt/fish (\%) & $\begin{array}{c}(0.042) \\
0.003\end{array}$ & $\begin{array}{c}(0.039) \\
0.003\end{array}$ & $(0.040)$ & $(0.010)$ \\
\hline & $(0.004)$ & $\begin{array}{l}0.003 \\
(0.003)\end{array}$ & $\begin{array}{c}0.003 \\
(0.003)\end{array}$ & $\begin{array}{c}0.0008 \\
(0.0009)\end{array}$ \\
\hline Divorce rate & 0.012 & 0.016 & 0.014 & $0.008^{\mathrm{b}}$ \\
\hline ADA ratings (av) & $\begin{array}{r}(0.013) \\
0.002^{\mathrm{c}}\end{array}$ & $\begin{array}{l}(0.012) \\
0.002^{\mathrm{b}}\end{array}$ & $\begin{array}{c}(0.013) \\
0.002^{\mathrm{b}}\end{array}$ & $(0.003)$ \\
\hline & $(0.001)$ & $\begin{array}{r}0.002^{\mathrm{b}} \\
(0.001)\end{array}$ & $(0.001)$ & $(0.0003)$ \\
\hline Inter-party comp index & -0.001 & -0.001 & -0.001 & -0.0002 \\
\hline State govt tax rev per cap & $\begin{array}{c}(0.002) \\
-0.014\end{array}$ & $\begin{array}{c}(0.002) \\
0.006\end{array}$ & $(0.002)$ & $(0.0004)$ \\
\hline & $\begin{array}{c}-0.014 \\
(0.11)\end{array}$ & $\begin{array}{c}0.006 \\
(0.107)\end{array}$ & $\begin{array}{c}-0.001 \\
(0.109)\end{array}$ & $\begin{array}{c}0.013 \\
(0.026)\end{array}$ \\
\hline Age 16-17 years & -0.010 & -0.001 & -0.005 & $0.043^{\mathrm{a}}$ \\
\hline Age 18-24 years & $(0.066)$ & $(0.062)$ & $(0.063)$ & $(0.025)$ \\
\hline Age $18-24$ years & 0.021 & 0.015 & 0.017 & -0.005 \\
\hline Age $25-44$ years & $\begin{array}{r}(0.031) \\
-0.027^{\mathrm{c}}\end{array}$ & $\begin{array}{r}(0.029) \\
-0.030^{\mathrm{b}}\end{array}$ & $\begin{array}{r}(0.029) \\
-0.029^{c}\end{array}$ & $\begin{array}{r}(0.007) \\
-0.014^{\mathrm{a}}\end{array}$ \\
\hline & $(0.015)$ & $(0.015)$ & $(0.015)$ & $(0.004)$ \\
\hline Age $45-64$ years & -0.021 & -0.025 & -0.024 & $0.023^{a}$ \\
\hline$\%$ Black & $\begin{array}{c}(0.034) \\
-0.003\end{array}$ & $(0.032)$ & (0.033) & $(0.008)$ \\
\hline & $\begin{array}{c}-0.003 \\
(0.004)\end{array}$ & $\begin{array}{c}-0.003 \\
(0.004)\end{array}$ & $\begin{array}{r}-0.003 \\
(0.004)\end{array}$ & $\begin{array}{c}-0.0003 \\
(0.001)\end{array}$ \\
\hline Adjusted $\mathbf{R}^{2}$ & 0.29 & 0.37 & 0.34 & 0.055 \\
\hline Dep var mean & 0.073 & 0.076 & 0.075 & 0.159 \\
\hline
\end{tabular}

${ }^{\mathrm{a}} \mathrm{p}<0.01 ;{ }^{\mathrm{b}} \mathrm{p}<0.05 ;{ }^{\mathrm{c}} \mathrm{p}<0.10$.

Appendix II Description and sample means of model variables

\begin{tabular}{lr}
\hline \multicolumn{1}{c}{ Variable } & Mean \\
\hline Snuff tax rate (\% wholesale price) & 0.08 \\
Chew tax rate (\% wholesale price) & 0.08 \\
Smokeless tax rate (\% wholesale price) & 0.09 \\
Cigarette tax rate (per pack, 1985 dollars) & 0.16 \\
Per capita personal income (100s, 1985 dollars) & 139.30 \\
High school graduates (\% population $\geqslant 25$ years) & 73.13 \\
population $\geqslant 25$ years) & \\
Metropolitan population (\%) & 63.39 \\
Fundamentalist population (\%) & 13.17 \\
No religion (\%) & 48.49 \\
Southern state & 0.22 \\
Strict laws restricting smoking & 0.48 \\
Hunters/fisherman (\% population $\geqslant 16$ years) & 32.02 \\
Divorce rate (per 1000 population) & 5.29 \\
Average ADA ratings US representatives† & 41.34 \\
Interparty political competition indexł & 33.09 \\
State government tax revenue per capita (1977 & 0.55 \\
dollars) & \\
Males 16-17 years (\% of males $\geqslant 16)$ & 4.27 \\
Males 18-24 years (\% of males $\geqslant 16)$ & 16.52 \\
Males 24-44 years (\% of males $\geqslant 16)$ & 42.18 \\
Males 44-64 years (\% of males $\geqslant 16)$ & 23.91 \\
Black males (\%) & 7.52 \\
Prevalence snuff use (\%) & 1.90 \\
Prevalence chew use (\%) & 3.90 \\
Prevalence smokeless use (\%) & 5.50 \\
\hline
\end{tabular}

$\dagger$ Americans for Democratic Action (ADA) ratings, based on the percentage of a representative's votes in agreement with the ADA's position, is often used as a measure of political liberalism.

$\ddagger$ The interparty political competition index indicates the degree to which state govenment is dominated by a particular political party (Democratic or Republican). It ranges from 0 (complete dominance by one party) to 50 (equal party strength).
1 US Department of Health and Human Services. Smokeless tobacco or health: an international perspective. Washington, DC: National Cancer Institute, 1992. (NIH Publication No 92-3461.)

2 Marcus AC, Crane LA, Shopland DR, Lynn WR. Use of smokeless tobacco in the United States: recent estimates from the current population survey. NCF Monographs $1989 ; 8: 17-23$.

3 US Centers for Disease Control. Use of smokeless tobacco among adults - United States, 1991. MMWR 1993; 42 : 263-6.

4 US Department of Health and Human Services. Smoking and health: a national status report. Atlanta, GA: US Department of Health and Human Services, Public Health Service, Centers for Disease Control, 1986.

5 US Centers for Disease Control. Cigarette smoking amon adults - United States, 1991. MMWR 1993; 42: 230-3

6 Baltagi BH, Levin D. Estimating dynamic demand for cigarettes using panel data: the effects of bootlegging, taxation, and advertising reconsidered. Rev Econ Stat $1986 ; 68: 148-55$.

7 Chaloupka FJ, Saffer H. Clean indoor air laws and the demand for cigarettes. Contemporary Policy Issues 1992 10: $72-83$.

8 Emont SL, Choi WS, Novotny TE, Giovino GA. Clean indoor air legislation, taxation, and smoking behaviour in the United States: an ecological analysis. Tobacco Control $1993 ; 2: 13-7$.

9 Keeler TE, Hu T, Barnett PG, Manning WG. Taxation, regulation, and addiction: a demand function for cigarettes based on time-series evidence. $f$ Health Econ 1990; 12: $1-18$.

10 Wasserman J, Manning WG, Newhouse JP, Winkler JD. The effects of excise taxes and regulations on cigarette smoking. F Health Econ 1991; 10: 43-64.

11 Kaiserman MJ, Rodgers B. Tobacco consumption declining faster in Canada than in the US. Am F Public Health $1991 ; 81$ : 902-4.

12 Phelps C. Death and taxes: an opportunity for substitution f Health Econ 1988; 7: 1-24.

13 The Tobacco Institute. The tax burden on tobacco. Washington, DC: The Tobacco Institute, 1986. 
14 Grossman M. The demand for health: a theoretical and empirical investigation. New York: Columbia University Press, for the National Bureau of Economic Research, 1972

15 Quinn B, Anderson H, Bradley M, et al. Churches and church membership in the United States, 1980. Atlanta, GA: Glenmary Research Center, 1982.

16 Smith TW. Classifying protestant denominations. Rev Religious Res 1990; 31: 225-45 (unpublished appendix obtained from author)

17 US Department of the Interior. 1985 National survey of fishing hunting, and wildlife associated recreation. Washington, DC: Fish and Wildlife Service, 1988.

18 Pertschuck M, Shopland DR. Major local smoking ordinances in the United States. Washington, DC: National Institutes of Health, 1989. (NIH Publication No 90-479.)

19 US Department of Commerce. State population and household estimates, with age, sex, and components of
change: 1981-87. Washington, DC: Bureau of the change: 1981-87. Washington, DC: Bureau of the
Census, Current Population Reports, 1988. (Series P-25, Census, Current Population Reports, 1988. (Series P-25,
No 1024.)
20 Maddala GS. Introduction to econometrics. New York: Macmillan, 1988.

21 Grossman $M$. The demand for cigarettes. $\mathcal{F}$ Health Econ $1991 ; 10: 101-3$.

22 Becker GS, Grossman M, Murphy KM. An empirical analysis of cigarette addiction. Am Econ Rev 1994; 84: $396-418$

23 Lewit EM, Coate D, Grossman M. The effects of government regulation on teenage smoking. F Law Econ 1981; 24: 545-70.

24 Chaloupka FJ. Rational addictive behavior and cigarette smoking. 7 Political Econ 1991; 99: 722-42.

25 DiNardo J, Lemieux T. Alcohol, marijuana, and american youth: the unintended consequences of government regulation. National Bureau of Economic Research, Working Paper No 4212 , 1992.

26 Manning WG, Keeler EB, Newhouse JP, et al. The taxes of sin: do smokers and drinkers pay their way? $¥ A M A$ sin: do smokers and

27 Kenkel DS. Prohibition vs taxation: reconsidering the legal drinking age. Contemporary Policy Issues 1993; 11 : 48-57.

Worldwide.
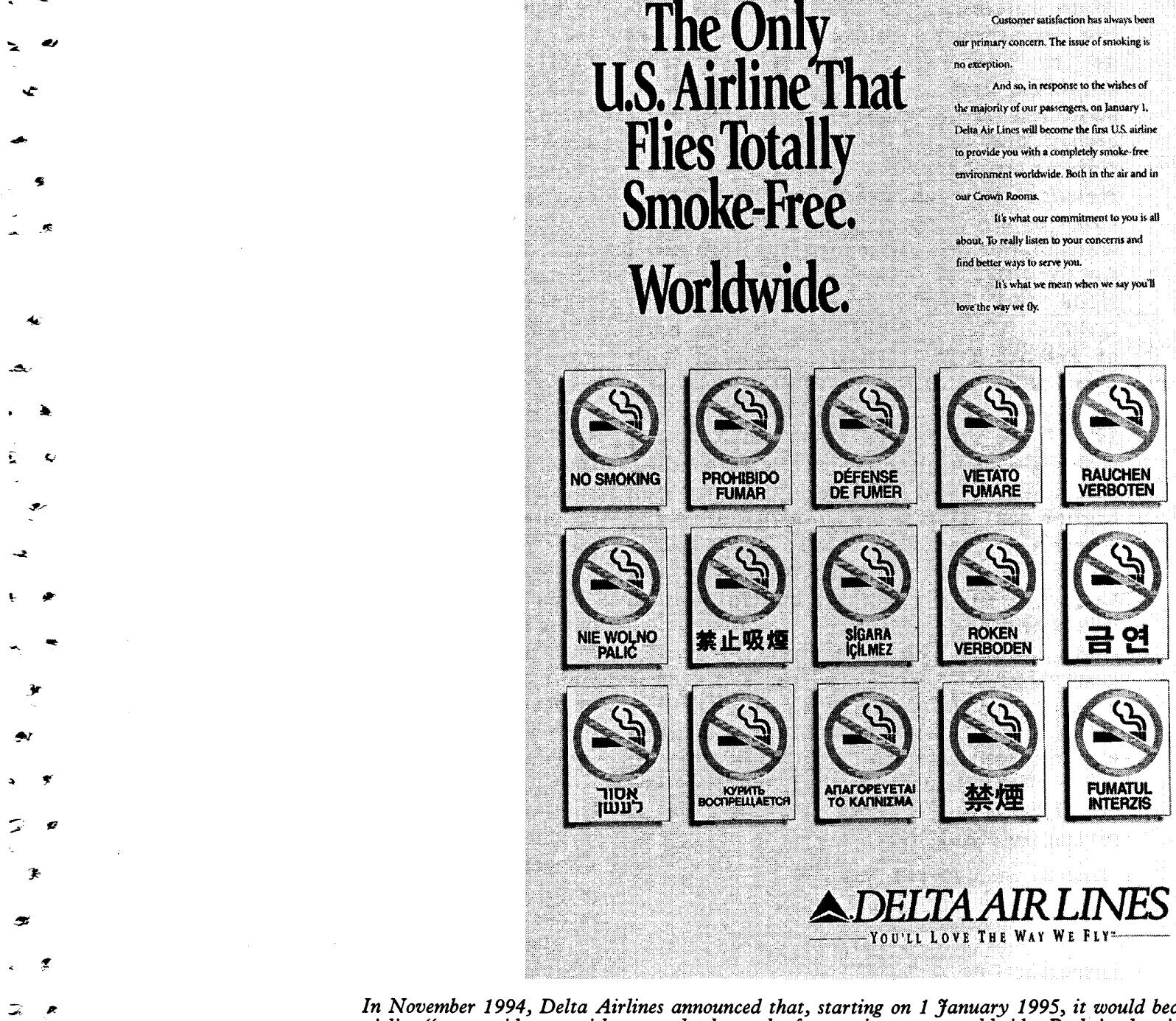

In November 1994, Delta Airlines announced that, starting on 1 fanuary 1995, it would become the first US airline "to provide you with a completely smoke-free environment worldwide. Both in the air and in our Crown Rooms." The advertisement shown above appeared in USA Today (15 November 1994) and in other major newspapers. 